\title{
Birds Names: \\ Embodyment of The Relationship Between Human and Environment
}

\author{
Yoga Pradana Wicaksono ${ }^{1}$, Sudartomo Macaryus ${ }^{2}$, and Ermawati ${ }^{3}$ \\ (yoga.pradana@ustjogja.ac.id ${ }^{1}$, sudartomo@ustjogja.ac.id² ${ }^{2}$ Ermawati@ustjogja.ac.id ${ }^{3}$
}

FKIP Universitas Sarjanawiyata Tamansiswa Yogyakarta ${ }^{1}$, FKIP Universitas Sarjanawiyata Tamansiswa

Yogyakarta $^{2}$, FKIP Universitas Sarjanawiyata Tamansiswa Yogyakarta ${ }^{3}$

\begin{abstract}
Birds are species that live in nature. Diverse natural characteristics become one of the determinants of bird species that live in the nature. This paper focuses on the study of the names of birds that live in the Javanese community. By using ethno-linguistic method, library data is also supported by field data from the observations and interviews with selected informants, namely citizens who have an interest and concern on local Javanese birds. The basic assumption of this research is that the informant has sufficient knowledge and taxonomy about the natural environment, including birds that live around them. In addition, given that one component of language is ideas or thoughts, language has the potential to be a response of a person and their thoughts about the environment around them.
\end{abstract}

Keywords: nature, birds, names, local

\section{Introduction}

One of the main components of a language is the thoughts or ideas in our heads. The thoughts and ideas will allow the language to have different meanings and response to its surroundings. As for the things around us that become important to us, we tend to express our thoughts and ideas about that something by giving a specific name. Thus the things that are out of our league won't get the same amount of attention or specific name for it. Differences between things that we are not really keen to pay attention to are most likely to be ignored and useless, their uniqueness is not to be seen. Considering the fact that languages contain our thoughts and ideas as human response to what is around them, names are seen as symbols and identities.

The mind also allows humans to make plans. In relation to birds life, humans can observe the characteristics of tree birds that have a potential to attract certain bird species, as stated by [1] who conducted a research on vegetation used in the parking lot of Yogyakarta State University (UNY). He said that vegetation is home to several animals. Thus, planning for vegetation development needs to be adjusted to the characteristics of the animals that are meant to be attracted.

Concrete environment is understood through the interaction between humans and nature that utilize nature. On one hand, nature provides various needs of human life. On the other hand, nature can also be a threat to human kinds. Various birds that exist in nature are named based 
on certain considerations, such as its sound, color, and size. Bird nurseries in Tanzania have been studied by [2]. He found that $50 \%$ of the names had positive connotations in male birds and $20 \%$ had negative connotations in female birds. The study of this name has the potential to be a storage, preservation and development space and inspire scientists to conduct similar studies in other geographical locations. In Javanese society there are various names that are singular, such as podang, perkutut, derkuku, and puter as well as names that are followed by attributes as specialists, such as jalak penyu (turtle starlings), jalak peta (map starlings), jalak uren, (uren starlings) and jalak Bali (Bali starlings). In the Indonesian language, the name of a pipit (sparrow) is similar to "emprit" in Javanese. In Javanese, emprit is divided into groups of birds, namely Javanese emprit, gandthil emprit, kaji emprit, and peking emprit.

The result of a research done by [3] shows that the dominant bird species are madu kelapa (Brown-throated sunbird), cabai panggul kelabu (grey-sided flowerpecker), cabai panggul kuning (yellow-sided flowerpecker), serindit Sulawesi (great hanging parrot), sri gunting jambul rambut (hair-crested drongo), walet polos (swifts), and walik malomiti (black-naped fruit dove). Their research was on about problems of species and families that found 29 species, 20 families with a population of 98 individuals. Of the 29 species, 15 of them were Sulawesi's endemic bird species. [4], [5] examined the names of animals and plants which were thrown into interactive media to recognize the names of animals and plants. The media used was a show about names of animals and plants which is also an interactive quiz to guess the name of the animal. The information collected can be read, listened to, and watched is more efficient. This interactive media can also be operated with a computer.

There are some birds that are on the edge of extinction, if it continues and there is no effort is made to rescue them, we might not be able to see them anymore. The extinction of birds will cause the name of the birds go with them to the hole of extinction and forgotten. Therefore, the study of names is useful for storing the names of birds that exist in nature and are known by the public. This paper focuses on the names of birds and chickens in the community, especially in the Javanese community.

\section{Theoritical Review}

There are more than one thousand birds species in Indonesia. Until today, the identification process of all birds species is still on going. A new finding was obtained in 2017 on Rote Island which was later given the name Myzomela Irianae. The name Myzomela is a genus of a newly discovered bird species, while Irianae uses the name of First Lady Iriani Joko Widodo. The discovery and naming indicate that not all bird species in Indonesia have been identified. Therefore, scientists continue to identify the diversity of birds in Indonesia. 


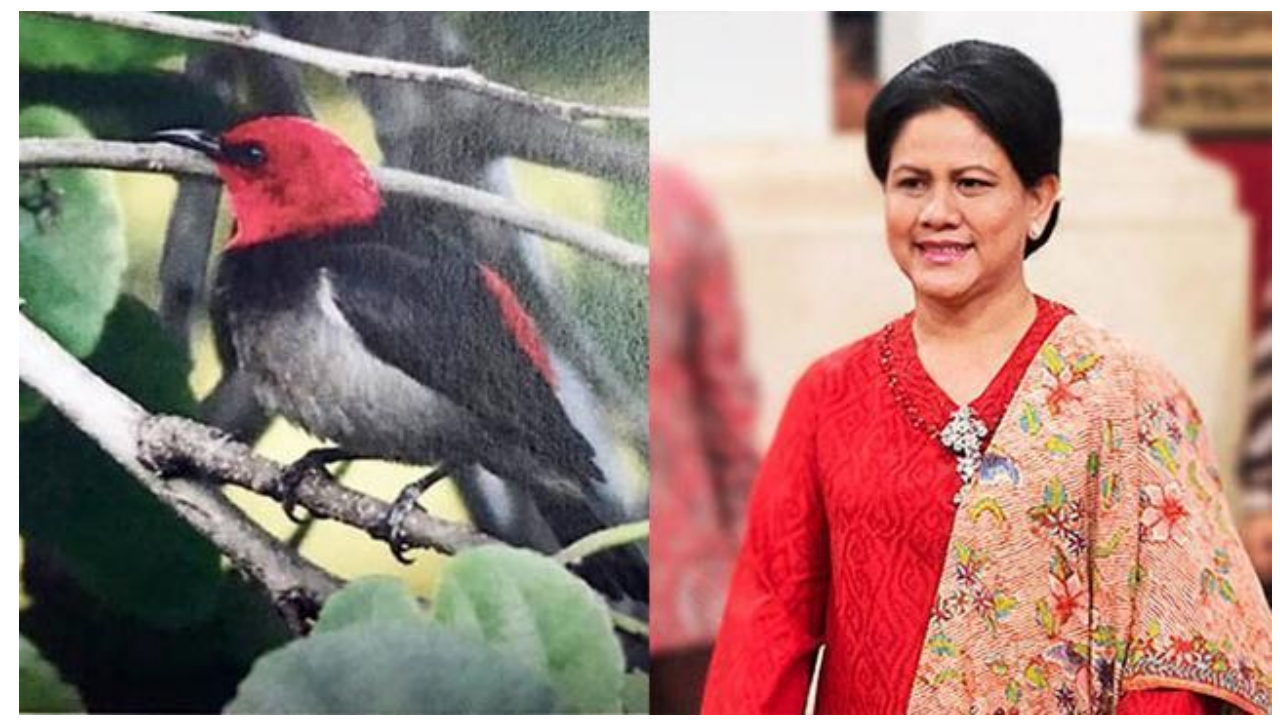

Figure 1: New bird species named Myzomela Irianae

(Sumber: https://m.suarasurabaya.net/app/kelanakota/detail/2018/197819-Nama-IbuNegara-Iriana-Jadi-Nama-Burung-Spesies-Baru,-Segera-Diluncurkan-)

In addition to several other new findings, birds also experience threats, one of the phenomena takes place on Bangka Island. The research on birds species in Bangka Island was dne around the tin mines which was restored 1, 2 and 3 years before the study, and in an adjacent natural secondary forest (not mined and natural on the Indonesian island) [6]. For the recovery of bird species in the ex-[6], the following three recommendations were recommended. First, the birds in the restored plot did not show an increase in the number of species. Recovery is needed to continue to be improved so that the population increases significantly, even after 16 years. Second, species varieties on restored land shows a rapid response starting in the first year after restoration and continuing to increase significantly for 3 years. Direct recovery is a recommendation to get a significant recovery of the wealth of bird species. Third, the plots that were restored in the third year were significantly lower in the surrounding natural secondary plots. Thus a period of 3 years is not enough to restore the population to the level of natural secondary forest which takes $>20$ years [6].

The island of Kalimantan has the highest rates of deforestation in the world mainly due to agriculture, logging, and other human activities. Anthropogenic fires are a major threat to a massive reforestation, but intensive fire prevention enables birds to recover from temporary setbacks [7]. The results show that land restoration will be effective by involving local communities and ensuring long-term maintenance, even small reforestation sites in Kalimantan can provide direct benefits for native biodiversity.

In Sulawesi birds life is related to the massive intensification of small-scale cocoa management that is currently affecting the agroforestry landscape of Sulawesi (Indonesia), the third largest cocoa producer in the world. Little is known about how this shift from diverse plantations to sun-filled cocoa will affect biodiversity that is functionally important in 
agroecosystems, and how this relates to broad landscape patterns in land use and natural ecosystems. We recorded birds in 43 different cocoa plots in woody and herbaceous vegetation and distances to the forest in two valleys around the Lore Lindu National Park in Central Sulawesi. The various of frugivorous and nektarivora species decreases with increasing distance to the forest, whereas granivorous birds increase in wealth. The results show that habitat generalization, a large increase in species diversity can be achieved by counteracting the current trend of cocoa intensification by providing incentives to conserve and replant diverse shade coverings [8] and [9].

In the early twentieth century, ornithology (theology of birds) underwent significant changes. So far, the changes have basically been studied by focusing on professional biologists who work at universities or state museums. This innovation, introduced by Agust Friedrich Thienemann, a hydrobiologist from Germany, in the form of hybrid ornithology, calls for specific spatial strategies that make optimal use of the characteristics of natural bacteria at work and that mobilize large networks of amateurs who are geographically dispersed. At the same time, his work also changed the space he shared with birds - materially, conceptually and culturally. [10] maintains Thienemann's ornithology which can only be understood by recognizing an ongoing interaction with the geographical and civil context in which it arises.

Other researchers, [11] used a molecular-based phylogenetic method and the reconstruction of the parent origin to examine the systematic and biogeographic relationships of the Indo-Pacific Pachycephalidae (whistlers) paserin bird family. Research results show that the different distribution patterns of wandering on the islands on both sides of the AustraloPapua continent are congruent with the arrangements and history of the islands in each region and show that palaeogeographic knowledge is important for understanding the evolutionary patterns in the islands. Another finding is that recolonization of continents from islands may be more common than previously thought.

The survival of several documented seeds through the K-Pg (The Cretaceous-Paleogene) shows that modern birds are relatively able to survive in the present of ecological stress. Modern birds are also able to develop and diversify into new niches in a short time. The exact response of Neornithines to the K-Pg boundary mass extinction is largely unanswered. The hypothesis proposed so far is based on the assumption of ecological adaptation of a phylogenetic flawed clade of "transitional shorebirds" [12], [13].

[14] examined the relationships of predatory birds and prey. The results of his experiments showed that the ability to fly in birds up to now has produced many questions in answer to disturbing predators that are disturbed. However, the number of studies carried out and even the smaller number of species studied makes it clear that to get a better understanding of the field more research is needed. However, studies that focus on predators, within the framework we present here are still scarce. We suggest that a focus on predatory behavior might be needed to advance our knowledge of the darkening of disturbed predators in the history of bird life [14].

\section{Method}

The knowledge about the role of social, cultural, and environmental factors in arranging the diversity of plants is important to to build the resilience of rural livelihoods to keep up with the global environmental changes. Impact studies describe that climate change will negatively affect sorghum yield in Sub-Saharan Africa [15]; [16]; [17]. Such projection raises questions 
about the availability of appropriate genetic resources and the ability of local breeding programs and breeding systems to develop the adaptations needed in a timely manner [16]. In Indonesia, especially Java, the natural environment is also a determinant of existing bird species. Therefore, the diversity of species that results in diversity of names is determined based on regional characteristics, namely agriculture, plantations, and agriculture.

Furthermore, the study of the names of birds and chickens uses the ethnolonguistic method that begins by collecting library data in the form of journals, news, articles, papers, books, and research results. The library data is supplemented by field data obtained through observation, participation, and in-depth interviews with informants from rural areas with the natural environment of rice fields, plantations and cultivation. The three informant environments are at the same time validating data through source irregularities (informants). The diversity of the natural environment is to obtain data on birds and chickens species that still exist in each environment. Data analysis is carried out continuously since the data provision stage. The interpretation is done lexically by utilizing the Javanese dictionary compared to the informant's understanding as a representation of the community. Further interpretation by conducting indepth searches through interviews to obtain data on the taxonomy of birds and chickens species that have been known by the public.

\section{Results and discussion}

Indonesia is a country that has an abundant natural resources. It can be seen from the variety of flora and fauna that can be found in Indonesia. As stated by [18] which stated that 30 thousand species of flowering plants or $10 \%$ of flora in the world can be found in Indonesia. This amount has not been added to the number of fauna which number is as big. The number of plant species show that it is directly proportional to the availability of food sources that are able to be offered by nature for the living creatures in them.

The different natural environment in Indonesia also distinguishes the types of flora and fauna species that inhabit an area. Due to the diversity that exists the emergence various names that are used to refer to an object is growing. The names certainly have relevance to the life style and level of education and knowledge of the community. One form of diversity in those names can be found in Javanese people who have many terms to name certain birds. These terms appear because the island of Java is inhabited by various species of birds. However, the terms for birds and poultry vary in each field. This is due to the uneven distribution of birds on Java. The distribution of bird species in Java according to [19] who is strongly influenced by land conditions such as agroforestry, intercropping, and border land.

Javanese people know many terms to name birds. Call it a sparrow or in Javanese known as emprit. There are varieties of sparrows, for example, known as emprit kaji, Peking, and gathil. The naming of birds in Javanese society can be classified based on sound (onomatopoeia), shape / color, and philosophical meaning, and based on similarities with other objects.

\subsection{Naming based on the sound (onomatope)}

Onomatopoeia or also known as the naming based on sound or imitation of sound produced by the object in question. This type of naming is usually used to mention animals that have a distinctive sound. Call it a gecko or in Javanese called təkck. This lizard-like animal got this name because the sound produced always sounds təkck ..... təkck... təkck. Besides that, 
Javanese people still know some onomatopoeia especially for the mention of bird species. Onomatope as the basis for naming birds is formulated based on the results of auditive observations. The results of the naming appear in the following data.

(a) emprit [əmprIt] sparrow

(b) deruk [dərU?] spotted dove

(c) prenjak [prənja?] White-rumped shama

(d) tengkek [tønke?] Kingfishers

(e) glathik [glațir] padda

(f) platuk [platU?] woospecker

(g) gagak [gaga?] crows

Data (a) emprit which in Indonesian is known as pipit (sparrow) is a type of birds to lay many eggs that are also known as enemies for rice farmers. This bird has many types, among which are the peking, kaji, geni emprit, and Javanese emprit. Although it has many types, emprit birds have a similar body posture which distinguishes is the color pattern of feathers that bind the body.

Even though it is known to have many types, it does not mean that birds do not have anything in common. The most obvious similarity is when these birds are fed by each parent. They will produce the whistling noise. However, when mature each bird is producing sound that is different. Emprit Java is very easy to find in the rice fields, especially land planted with rice. The large number makes this bird considered a pest for farmers. This bird has a white color on the chest to the stomach, brown on the back, and black on the neck and tail. The distinctive sound produced by this bird is the prit prit which is often heard by farmers when farming. Therefore, this bird is called emprit by farmers because of the habit of producing such sounds.

The next type of sparrow is Peking emprit. This bird has a slight difference compared to Javanese emprit. The difference lies in the color of the hairs on the chest and abdomen because it has black spots. The next difference, emprit peking does not produce a sound like Javanese emprit. The sound produced is a little different because it will sound peking ... peking ... peking ... especially when flying. This distinctive voice is what farmers later called empathy.

Data (b) deruk (Spotted dove) which has a similarity to a dove, a puter, and a turtledove. Javanese people put this group of birds based on their voices called anggung. Therefore, this group of birds is called perungan while sounds like starlings, magpie, parakeets are called ocehoceh (babbling). Derkuku or also known as deruk. Actually derkuku are similar to pigeons, puter and perkutut. However, so that they can be distinguished, each is called by a different name. The name differences are based on body size, color, and sound. Derkuku will be difficult to distinguish from pigeons and puterons if only seen from their body shape because these three birds have almost the same size. Because it has similarities with pigeons and puter birds, the creaking bird is more often called the derkuku. This happens because people want to more easily distinguish between the three birds. The word derkuku is obtained from the typical chirp produced by this bird, tekukur kwok ... tekukur kwok ....

Data (c) of the murai prenjak (White-rumped shama) birds in the Javanese community signaled the presence of guests when they chirp. Modern society think this phenomenon as a myth. Chirping is produced by birds that people know by the name prenjak. The community considers that if there are prenjak birds chirping around the house, it is a sign that there will be people visiting, so that the community concerned will try to give some entertainment. For information, Javanese people are people who like to glorify guests by taking out all the food they have to serve to guests who visit at home. Somehow this myth developed, but until now 
there are still many people who believe, especially those who live in villages.

The word prenjak actually comes from the chirp produced by this bird. They do not actually sound like prenjak. However, if you pay close attention, you will hear a chirp that sounds prenjek .. prenjek .. prenjek. The identification of the sound is the basis for naming the bird.

Tangkek bird, as in data (d), its naming is also based on sound identification. Tangkek name can be categorized as onomatopoeia because of the chirp produced. This bird is known as a fish eater and likes to nest on steep cliffs. The word tengksk comes from the chirping that is commonly heard when this bird flies. Chirps that are often heard sound like $k e k \ldots k e k \ldots k e k . .$. $k e k$... kek ... The word tengksk comes from two words, namely ting + kek. The word ting is a Javanese language which means an imitation of the bells while the word kek is taken from the song of the bird. Thus, the community calls the word tengksk meaning chirp that is always repeated.

The glathik bird in data (e) is public interest because it understands the color of its shiny gray feathers. While the beak is red in mature birds. While the young ones are black. Glathik naming is based on the characteristics of the sound issued by the bird which is identified thik, thik, thik. From the sound side there are no variations and features. But people who love birds prefer the color of their feathers and beak. Thus, the name of the bird can be categorized based on the sound produced.

Woodpecker or pelatuk on (f) or known by the name of the platuk in Javanese society is a bird which natural habitat is inside a tree trunk. Actually, this bird can be found all over the world, has many species, and different names. Specifically on the island of Java, this bird is known as a woodpecker. The name is not derived from the chirp produced, but from the habits that are often carried out by this bird. Woodpeckers have a habit of making nests on large tree trunks. The tree is perforated by being pecked using a beak so that it produces a tuk tuk tuk sound. Based on the nesting activity, the community is acquainted with birds that always produce tuk tuk tuk sounds so that these birds are nicknamed the name woodpeckers.

The crow or gagak in the data $(\mathrm{g})$ falls into the category of birds named after onomatopoeia. This bird, which is identified as a bird of death, has a chirping that some people find scary. In the past, until the 1970s there was no community that had a desire to keep crows because they were related to the myth of death. In addition to having black feathers all over his body, crows have a monotonous chirp, which is gwrak gwrak gwrak. The sound produced is then used by the community to name this bird. The chirping of the phantom of the phantom of the phantom, then this is then simplified into a crow.

The frightening crow myth inspires WS Rendra which appears in the poem "Hunger People Prayer" or Doa Orang Lapar as shown in the following lyrics.

\author{
Kelaparan adalah burung gagak \\ yang licik dan hitam \\ jutaan burung-burung gagak \\ bagai awan hitam
}

Allah!

Burung gagak menakutkan

dan kelaparan adalah burung gagak

selalu menakutkan

The black and frightening perception of the black crow strengthens the view of the 
Javanese community that links the presence of the crow as a sign of sorrow, death.

\subsection{Naming Based on the Colour and Shape}

The shape and color are the characteristics of birds which form the basis of naming birds. The shape and color are the result of visual observation. Naming of birds based on visual observations appears in the following data.

(h) emprit kaji [omprIt kaji] white headed sparrow

(i) emprit geni [əmprIt gəni] 'fiery' sparrow

(j) cuk urang [cU? uray] Ceyx fallax

(k) srigunting [sriguntIy] drongo

Data (h) emprit kaji and (i) emprit geni basically produce same noise that is almost the same as Javanese emprit. Therefore, all names use the core elements of emprit accompanied by the attributes of the kaji, geni, and java. Attributes become distinguishing features identified from the color of the feather in whole or in part. The difference only lies in the short length and small sound produced. It is called emprit kaji because this bird has a shape that resembles someone who has finished the pilgrimage because it has a white head and then brown on the neck down. So it's as if a pilgrim wearing a white cap. Unlike the case with the geni emprit in the data (i). Geni can be translated into Indonesian as fire. It is likened to fire because emprit geni has reddish-yellow feathers like a burning fire. While the Javanese emprit pointed at the black feathered finches.

The cuk urang birds in data (j) have similarities to the tengksk. The difference is that the cuk urang is smaller in size. Though they do share things in common which are the same color and they both prey on fish. The word cuk urang comes from the word cucuk which means beak and urang which means shrimp. So, it can be translated the word cuk urang means bird beak shrimp. The naming is based because this bird likes to eat fish including one of them is small shrimp. Because of this, people came to know this bird as cuk urang or shrimp-eating birds.

The srigunting bird in data $(\mathrm{k})$ has an ecotype that is almost the same as a swallow. The name srigunting is identified from the shape of the tail which has similarities to the scissors. The naming assumes the naming is done after the public knows the scissors.

Unlike sriti birds, srigunting birds have tails that are branched to resemble scissors. To distinguish between sriti birds, people then call this bird by the name of srigunting. The word sri is usually carried by those who have an honorary degree. The relationship with this bird is called as $\mathrm{Sri}$ because it has a very high economic value in international trade. The word scissors are used because the tail of this bird really resembles scissors.

\subsection{Naming based on the philosophy}

Philosophical considerations are the result of human reflection about a phenomenon that occurs in their environment. In relation to naming birds, philosophical considerations represent the results of reflection and contempation. Thus the naming of this type is an advanced stage of the naming method based on the results of auditive and visual observations. Bird names are formulated based on philosophical considerations, shown in the following data.

(1) kutut [kutUt] zebra dove

(m) puter [putər] Eurasian collared dove

(n) gemak [gəma?] quail 
(o) emprit gathil [əmprIt gațIl] 'insect eater sparrows'

(p) podhang [poḍan] Black-naped oriole

Giving a name to an object usually indicates the relationship between that thing and human. If you look closely, there is history and origin of why the name is attached to the object. In other words it can be stated that the name contains meaning on the object carried. We can take an example of the naming the types of birds in Java.

The names of birds can actually be used to express the culture of the community in the past. This is due to the meaning contained in the name of a bird contains philosophical values that are relevant at that time. Some data revealed, the name used for various types of birds illustrates the hopes, ideals, and sadness of the community.

Data (1) kutut birds are still the part of the columbidae family. In Javanese society, this bird is considered as a bird that has high mystical value. According to Chairman of the Association of Conservation and Local Perkutur Lovers All over Indonesia (P4LSI), Giyanto Hadi Prayitno, kutut is considered a symbol of perfection. This is because Javanese people recognize the principle of limo wasta or five perfection for Javanese people consisting of a wisma homestead, curigo (heirloom), turangga (vehicle), garwa (wife), and kukilo (bird). Those five wasta are considered as a form of perfection for Javanese people, especially the king.

Today, kutut could only be owned by nobles or kings. Commoners were not permitted to raise kutut because it was considered inappropriate and believed to have a magical effect on their owners. Kutut was maintained because it symbolizes status for the nobility and the king and is considered to give good luck to these circles. Therefore, this bird is called a curse or only proper (proper) maintained by someone who has a high position and social.

Just like the kutut, Javanese society in giving names to the puter bird also has a philosophical meaning related to life. The puter in data $(\mathrm{m})$ is preserved because it is considered a bird of blessing and calm in Javanese philosophy. His monotonous and repetitive chirping, "Kuuk gukwuk kwok", is interpreted as a blessing that always revolves continuously. Therefore, this bird is called puter or can be translated in Indonesian which means 'spin / spin'. The connection between the meaning of the play and the sustenance is due to the chirping of this bird which is considered to bring peace and tranquility so as to provide positive energy for its owner. The stimulus made the people who owned the puter birds enthusiastic and enterprising in their work so as to bring stability to life for their efforts.

Another philosophical meaning of the puter so that it can be said a blessing can also be expressed from the type of food. This type of birds like to consume grains such as corn or beans which are identical to the agricultural products of the agrarian community. Therefore, this bird is considered easy to maintain because its food can be obtained from agricultural products. In addition, these grains also have a relatively lower price compared to fruit. On this basis the community considers that the puter bird is a blessing animal because it is easy and inexpensive to care. In addition, the crop eaten by the puter is also considered to bring benefits to the next crop.

Subsequent data related to naming based on philosophical meaning can be found in quail data (n). This bird, in Javanese society, is known by the nickname manuk tumak / gemek. Physically, quail is almost like a chicken, but has a much smaller size. The average quail has the size of an adult's hand grip. Wild quails are easily found in rice fields because they usually nest in the ground near food sources such as grains (rice, corn, beans, etc.) and insects.

Because of its size which is only as big as an adult's grip, Javanese people refer to it as gemak. The word gemak is actually an acronym from Javanese which is gripped to mind. The word can be translated into Indonesian as 'nice to hold'. Easy to hold because of its small size, 
downy like a chicken, and when held snugly with a human palm.

The bird is a night bird species known by the public as gathil emprit / kedasih (o). Actually this bird is known by many names, such as tititir, daradasih, or ucungwing. They are famous as birds that have never made a nest. In breeding, these birds will entrust their eggs to other bird's nests because the loving bird is a type of bird that does not care for its own cubs.

According to one of the speakers, Babe Suroso, which can be traced on the Jogja Archive Youtube channel, stated that the bird of love is a bird that has a sad story. It is said that the bird is a bird whose habitat is not in the land of Java, but for some reason got lost to the island. Alienation in a new place causes the birds to feel lonely and sad because they have no friends. Deep sadness makes this bird always cry in their daily life, especially in the late afternoon. That is what causes the chirping of the birds sounding miserable as if crying.

Like the word gemak, the word kedasih in Javanese is an acronym for the word tadah asih. The word can be interpreted as an expectation of love from other creatures. This hope is due to the bird being in alienation and hoping to return to its original land. This happened because it had once been cheated by an emprit bird (sparrow) who broke the promise that it would show the way home after the bird was willing to take the sparrow back to Java.

Naming of birds based on similarities with other objects can be found in kepodang (p). This bird is known by the public as a dandy, either because of the beauty of the color of its feathers or because of its hygiene compared to other birds. Not only found in the forest, Kepodang also has a habitat for living in rural areas. That is why these birds are often encountered in residential areas where nature is still awake. In Javanese society, especially Central Java, kepodang is usually used for the seven-month tradition (mitoni). A salvation tradition for women with a gestational age of seven months.

In order to obtain good-looking offspring, in the opinion of Javanese people, women who are seven months pregnant must consume kepodang meat. The philosophy is the frog is a bird that is considered good-looking because of the color of its feathers and dandy because of its cleanliness. This bird, which has another name Bincarung in Sundanese, has a dominant yellow feather color combined with black. At first glance this color is similar to a ripe banana. The people of Central Java consider that kepodang has similarities with bananas because of their color. As a result, this bird is given a name that is almost similar to a banana.

If translated the word kepodang comes from the base word podang then obtains affixation ke. Podang can be translated as gedang and is transformation of sagedang in Javanese. The word kepodang can be translated as segedang or banana in Indonesian. Because of its similarity with bananas, the people of Central Java give the name of this bird with the term segedang or one banana.

The origin of the name Kepodang is a form of transformation from the word segedang in Javanese. The community gave this name based on its similarity to other forms that were first known. At first glance this bird will look like a comb of bananas from a distance, especially when this bird is in the tree. This is because the kepodang has a distinctive golden yellow color that is striking like a banana.

\section{Conclusion}

The discussion above shows that Javanese people have a certain strategy in naming birds in their natural environment. The strategy appears as a result of observation and contemplation. Auditive observation results in identification of bird names formulated based on sound. Visual 
observation results in identification formulated based on color, shape and size. Through contemplation it produces identification based on deeper understanding of phenomena related to the natural life of birds.

Proximity and function have the potential to be extended to naming bird body parts, life processes, and characteristics of each body part. The latter thing requires a separate study to get a deeper explanation of the characteristics and functions.

\section{References}

[1] Sari VR, Hidayah R. Kajian Vegetasi pada Area Parkir Kampus. Ecotrophic. 2018;12(2).

[1] Chiwanga FE, Mkiramweni NP. Ethno-ornithology and onomastics in the Natta community, Serengeti district, Tanzania. Heliyon [Internet]. 2019 Oct;5(10):e02525. Available from: https://linkinghub.elsevier.com/retrieve/pii/S2405844019361857

[3] Rudini, Labiro E, Ihsan M. Keanekaragaman Jenis Burung pada Kawasan Hutan Lindung KPH Dampelas Tinombo di Desa Sibualongkec. Balaesang Kab. Donggala. War Rimba. 2016;4(2).

[4] Ananda RF. Perancangan Media Interaktif Mengenal Nama-nama Hewan dan Tumbuhan untuk Anak Usia Dini. Dekave [Internet]. 2014;3(1). Available from: http://ejournal.unp.ac.id/index.php/dkv/article/view/5638

[5] Firmantoro K, Anton, Nainggolan ER. Animasi Interaktif Pengenalan Hewan untuk Pendidikan Anak Usia Din. Tecno Nusa Mandiri. 2016;8(2).

[6]. Passell HD. Recovery of Bird Species in Minimally Restored Indonesian Tin Strip Mines. Restor Ecol [Internet]. 2000 Jun;8(2):112-8. Available from: http://doi.wiley.com/10.1046/j.1526-100x.2000.80017.x

[7] Helms JA, Woerner CR, Fawzi NI, MacDonald A, Juliansyah, Pohnan E, et al. Rapid Response of Bird Communities to Small-Scale Reforestation in Indonesian Borneo. Trop Conserv Sci [Internet]. 2018 Jan 18;11:194008291876946. Available from: http://journals.sagepub.com/doi/10.1177/1940082918769460

[8] Bhagwat SA, Willis KJ, Birks HJB, Whittaker RJ. Agroforestry: a refuge for tropical biodiversity? Trends Ecol Evol [Internet]. 2008 May;23(5):261-7. Available from: https://linkinghub.elsevier.com/retrieve/pii/S016953470800092X

[9] Clough Y, Dwi Putra D, Pitopang R, Tscharntke T. Local and landscape factors determine functional bird diversity in Indonesian cacao agroforestry. Biol Conserv [Internet]. 2009 May;142(5):1032-41. Available from: https://linkinghub.elsevier.com/retrieve/pii/S0006320709000482

[10] de Bont R. Poetry and Precision: Johannes Thienemann, the Bird Observatory in Rossitten and Civic Ornithology, 1900-1930. J Hist Biol [Internet]. 2011 May 6;44(2):171-203. Available from: http://link.springer.com/10.1007/s10739-009-9209-9

[11] Jønsson KA, Bowie RCK, Moyle RG, Christidis L, Norman JA, Benz BW, et al. Historical biogeography of an Indo-Pacific passerine bird family (Pachycephalidae): different colonization patterns in the Indonesian and Melanesian archipelagos. J Biogeogr [Internet]. $2010 \mathrm{Feb} ; 37(2): 245-57$. Available from: http://doi.wiley.com/10.1111/j.1365-2699.2009.02220.x

[12] Feduccia A. The problem of bird origins and early avian evolution. J Ornithol [Internet]. 2001 Jun;142(S1):139-47. Available from: http://link.springer.com/10.1007/BF01651452

[13] Robertson DS, McKenna MC, Toon OB, Hope S, Lillegraven JA. Survival in the first hours of the Cenozoic. Geol Soc Am Bull [Internet]. 2004;116(5):760. Available from: https://pubs.geoscienceworld.org/gsabulletin/article/116/5-6/760-768/2092

[14] Lind J, Jakobsson S, Kullberg C. Current Ornithology Volume 17 [Internet]. Thompson 
CF, editor. New York, NY: Springer New York; 2010. 1 p. Available from: http://link.springer.com/10.1007/978-1-4419-6421-2

[15] Schlenker W, Lobell DB. Robust negative impacts of climate change on African agriculture. Environ Res Lett [Internet]. 2010 Jan;5(1):014010. Available from: https://iopscience.iop.org/article/10.1088/1748-9326/5/1/014010

[16] Ramirez-Villegas J, Jarvis A, Läderach P. Empirical approaches for assessing impacts of climate change on agriculture: The EcoCrop model and a case study with grain sorghum. Agric For Meteorol [Internet]. 2013 Mar;170:67-78. Available from: https://linkinghub.elsevier.com/retrieve/pii/S0168192311002814

[17] Westengen OT, Okongo MA, Onek L, Berg T, Upadhyaya H, Birkeland S, et al. Ethnolinguistic structuring of sorghum genetic diversity in Africa and the role of local seed systems. Proc Natl Acad Sci [Internet]. 2014 Sep 30;111(39):14100-5. Available from: http://www.pnas.org/lookup/doi/10.1073/pnas.1401646111

[18] Kartawinata K, Associate R. Dua Abad Mengungkapkan Kekayaan Flora dan Ekosistem Indonesia. Jakarta; 2010.

[19] Sulistyadi E. Kemampuan Kawasan Nir-Konservasi dalam Melindungi Kelestarian Burung Endemik Dataran Rendah Pulau Jawa Studi Kasus di Kabupaten Kebumen. Biol Indones [Internet]. 2010;6(2). Available from: http://ejournal.biologi.lipi.go.id/index.php/jurnal_biologi_indonesia/article/view/3162 